\title{
Beyond the Veil of Fantasy: "The Book of Thel" and the Critique of Romantic Ideology
}

\author{
Ghiasuddin Alizadeh ${ }^{1}$ \& Shideh Ahmadzadeh ${ }^{2}$ \\ ${ }^{1}$ PhD candidate of English Literature, Shahid Beheshti University, Tehran, Iran \\ .Orcid.org/oooo-0oo2-4119-2251. Email: Ghiasuddin.alizadeh@gmail.com \\ ${ }^{2}$ Professor of English Literature, Shahid Beheshti University, Tehran, Iran
}

Received August 21, 2017; Revised September 13, 2017; Accepted November 30, 2017; Published December o9, 2017.

\begin{abstract}
Romanticism is usually conceived as a return, from the corrupt political and social milieu, to the purity and innocence of Nature. Romantics, it is argued, aspired for liberty and freedom from the yoke of oppressive social institutions, and cherished the 'fantasy' of an ideal society built upon 'true' humane values. However, the ultimate failure of the French Revolution in realizing the romantic ideals of liberty, equality, and fraternity opened the eyes of some of the Romantic poets to the inherent antagonism, constitutive of human existence as such, namely, the impossibility of a return to a prelapsarian sense of innocence, of the prospect of building a society purged from taints of evil and ideological conflict. This research aims to read William Blake's The Book of Thel as the poet's critique of Romantic ideology and fantasy. Through a close analysis of the poem, informed by the ideas of Slavoj Žižek, this article tries to reveal Blake's insight into the ontological perversity of human civilization and the relationship between the Romantic notions of innocence and experience.
\end{abstract}

Keywords: Romantic ideology; innocence; experience; fantasy; French Revolution

\section{Introduction}

In Fearful Symmetry: A Study of William Blake, Northrop Frye (1947) drew on the similarity between the vales of Har and Beulah (which later on in Blake's career symbolizes the world of primordial life and energy before passing into the world of generation) in order to read Thel's journey to the underworld and her subsequent retreat as an example of the soul's refusal to take on physical form and become reality:

“Thel longs to be of 'use,' that is, to develop her potential life into an actual one and hence come into our world of Generation. Like all seeds, she has to be buried in her 'grave-plot' in order to spring to life... But, hearing the groans of a fallen world tormented in its prison, she becomes terrified and escapes back to the unborn world. The 'shriek' she gives is therefore that of the disappearing ghost or the uprooted mandrake, not the wail with which a baby announces its birth.” (p.233)

(c) AesthetixMS 2016. This Open Access article is published under a Creative Commons Attribution Non-Commercial 4.0 International License (http://creativecommons.org/licenses/by-nc/4.o/), which permits non-commercial re-use, distribution, and reproduction in any medium, provided the original work is properly cited. For citation use the DOI. For commercial re-use, please contact editor@rupkatha.com. 
Many critics seem to have followed Frye's lead in this case. Jonathan Roberts (2007), in William Blake's Poetry, claims that the poem "employs pastoral motifs to narrate the symbolic story of a soul's encounter with experience” (p.26). John Beer Williams (2005), in William Blake: A Literary Life, believes that "Thel herself is to be viewed as a figure of innocence facing experience, a being still retaining her visionary nature, but contemplating descent into the materiality of the world - including entry into a human form" (p.89). Brian John (1974), in Supreme Fictions, maintains that "innocence" is "a state through which the self must pass - as Thel and Oothoon to varying degrees learn" (p.29) and concludes that "the poem describes the failure of self to move from unenlightened innocence to experience" (p.42), while Harold Bloom (2008), in William Blake, states that "In The Book of Thel Blake shows us the soul trembling on the threshold of experience. In Visions of the Daughters of Albion, Thel, who has become Oothoon, crosses the threshold" (p.186). Also, Christine Gallant (1978), in Blake and the Assimilation of Chaos concludes that "Thel, too, in her Book is invited to move from her initial State of innocence to its contrary State of Experience in "the land unknown" which may lead eventually to a higher "redeemed" State" (p.45).

In recent decades, especially as a result of the widespread shift in philosophical debates, some critics have tried to approach The Book of Thel from a different perspective. In his "The Book of Thel' and the Romantic Lament", Scott Simpkins (1988) focuses on the problematic nature of language and the way the poem compensates for this problem through what he calls the "technique of questioning." He concludes that

“the use of the question...seems to confirm Blake's recognition of a need to compensate for the inadequacies of language, since questions-posited as subordinate forms-announce an incomplete state through their role as a mere component of language, and not an autotelic end unto themselves. As a result, questions become a potential remedy for the failure of language, with The Book of Thel providing a distinct presentation of this discovery" (p.25).

Laura Quinney (2009) offers a more philosophically oriented reading of the poem in her William Blake on Self and Soul. In his early years as a poet, Quinney argues, Blake was concerned with the psychological effects of failing to account for reality and meaning through materialism and empiricism. To her, The Book of Thel, as well as Blake's other early works, "dramatize his understanding of how empiricism gives rise to despair (p.28). Marjorie Levinson's “The Book of Thel' by William Blake: A Critical Reading" is an attempt to read the poem by focusing on the concept of 'desire'. Taking David Perkins' claim that "the name Thel goes back to a Greek root meaning desire" (Levinson, 1980, p.287), Levinson argues that the poem is somehow an allegorical account of Thel's progress in her quest to discover her origin and identity. More recently, in "Thel, 'Thelyphthora', and the Daughters of Albion” E. B. Murray (1981) has strongly rejected the idea that Thel's root meaning is desire. Instead, drawing on biographical information about Blake and the fact that Blake did not begin learning Greek until a few years after he wrote the poem, he contends that "the only apposite meaning Blake could have supposed his prospective contemporary audience to associate with the word 'Thel' was the word 'female' which Madan's apposite title had made notoriously current" (p.276).

There is a common ground between these two critical currents in spite of the differences which set them apart. They both base their arguments on the presupposition that the "vales of 
Har", Thel's original habitat, is different in nature from the dark underworld where she enters near the end of the poem. That is to say, both views take for granted the point that what they call "innocence" and "experience" are two "different" states in the life of human beings, and take the poem as a stage where the conflict between these two states is put on display. As Frye claimed,

"The irony suggested by the contrast of the two states of innocence and experience is deepened by the tragedy of Thel, the failure to overcome that contrast which is symbolized by all unborn forces of life, all sterile seeds, all the virginity that results from fear. The Book of Thel thus represents the failure to take the state of innocence into the state of experience, a failure which establishes one of the poles of the fallen world." (Frye, 1947, p. 238)

This article offers a new reading of The Book of Thel by trying to prove the point that, unlike the common critical understanding, innocence and experience are not two contradictory states but the two sides of the same world. That is to say, it is true the underworld symbolizes the world of experience; however, (as the article tries to prove) it is a mistake to take the world of innocence and the world of experience as two different worlds, and account for the passage from one state into the other as a failure. Experience, as the article argues, is the rising bed of innocence, and Thel's journey to the underground symbolizes her realization of this significant issue.

\section{Discussion}

The "vales of Har", the original setting of the poem, is a utopian ideal of a city-state in which even the feeblest and the most pathetic objects of Nature have a determined place inside the over-all picture, each having its own specific function and role to perform. In fact, the poem portrays an epitome of the doctrine of the Great Chain of Being according to which, as Abelard claims,

"all things, both good and bad, proceed from a most perfectly ordered plan, that they occur and are fitted to one another in such a way that they could not possibly occur more fittingly" (as cited in Lovejoy, 1964, p. 72).

The fragile Lilly, the tender Cloud, the week Worm, and the matron Clay all follow a precise order and have their own responsibilities, the most important of which is to cast away their narcissistic self-infatuation and sacrifice themselves for the good of the others. As the Cloud reveals to Thel: "Everything that lives / Lives not alone, nor for itself" (Blake, 2007, p. 103). In other words, Thel lives in an "organic" world, where "everything supports and underlies everything else" (McFarland, 1981, p. 40).

From a psychoanalytical viewpoint, such a conception of society is a fantasy construct dominating the life of the subject. Fantasy, according to Žižek, functions as a support against the traumatic realization that the Other, i.e., the symbolic order, is lacking and as such fails to complete the lacking subject herself: "reality" stabilizes itself when some fantasy-frame of a "symbolic bliss" closes off the view into the abyss of the Real. Far from being a kind of dreamlike cobweb that prevents us from "seeing reality as it effectively is," fantasy constitutes what we call reality. (Žižek, 1993, p. 118) That is to say, social reality suffers from an inherent antagonism, from an internal conflict which is the result of the self-reflexive nature of the symbolic order. (Žižek, 
2008, p.45) Thus, one of the prerequisites of living in such an environment is to conceal the "antagonistic kernel" and to present another image of the social reality which is empty of any internal conflict, i.e., a world which is unified in all its levels and moves, as a whole, towards an ideal telos. (ibid) In other words, the fundamental social fantasy is that of a world which is innocent by nature, a dream-land where no class domination can be found and all the members of society live in equality and mutual fraternity.

It was such an ideology that dominated the early Romantic thought. The idea of liberty and equality for all human beings, irrespective of their race, color, and social status, had a powerful sway over the mind of the Romantic poets. As Victor Hugo (1802-1885) put it, "Romanticism...is nothing but liberalism in literature" (as cited in Popkin, 2013, p.98). The world which Blake portrays in The Book of Thel can be considered to be the ideal world of the Romantics. Of course, Jean-Jacques Rousseau's resentment toward social institutions and his criticism of the existing social order became very popular during the Romantic period. (Margalit, 1997, p. 77) According to Rousseau, "human beings...had fallen from their primeval spiritual harmony with nature as a result of greed and had fallen into a depraved state of materialism, thereby producing the corrupt modern state" (as cited in Murray C. J., 2004, 811). Equally, the "vales of Har" is a world purged from the contamination of social institutions and cleansed from the vile of social antagonism. In this world, no one is to blame as long as they do not deviate from the place allotted to them in the Whole. There, even the image of destruction, of the flower being cropped and eaten by the lamb, is romanticized:

Thy breath doth nourish the innocent lamb; he smells thy milky garments, He crops thy flowers, while thou sittest smiling in his face, Wiping his mild and meekin mouth from all contagious taints. (Blake, 2007, p. 101)

Having heard the words of the Clod of Clay, Thel sees through the vanity of her former complaints about the ephemerality of life and willingly embraces the Clod's view. What exactly happens that Thel, who had already resisted the reasons given by the Lilly and the Cloud, succumbs to the Clod's argument? Is that because the latter provides more convincing reasons and yields more knowledge about the true state of events that Thel decides to follow her line of thinking? In order to shed light on this point, it is better to read the poem in the light of Blaise Pascal's (1623-1662) famous comment on the necessity of wager on the existence of God. Trying to persuade his imaginary friend, who believes that he is made in such a way that he can never believe in God, Pascal says:

So concentrate not on convincing yourself by increasing the number of proofs of God but on diminishing your passions. You want to find faith and you do not know the way? You want to cure yourself of unbelief and you ask for the remedies? Learn from those who have been bound like you, and who now wager all they have. They are people who know the road you want to follow and have been cured of the affliction of which you want to be cured. Follow the way by which they began: by behaving just as if they believed, taking holy water, having masses said, etc. That will make you believe quite naturally, and according to your animal reactions. (Pascal, 1999, pp. 155-156)

The same Pascalian gesture is discernible in these words by the Clod: "But how this is, sweet maid, I know not, and I cannot know; / I ponder, and I cannot ponder; yet I live and love" (Blake, 2007, p. 104)? The Clod believes without knowing the reason, without having found the 
answer to her question. In other words, what distinguishes the Clod from the other characters is that, while the others are fully dissolved in their ideological context, she maintains her distance towards what she believes in. However, notwithstanding this distance, she is more ideological than the other subjects. As Žižek puts it,

"An ideological identification exerts a true hold on us precisely when we maintain an awareness that we are not fully identical to it, that there is a rich human person beneath it: 'not all is ideology, beneath the ideological mask, I am also a human person' is the very form of ideology, of its 'practical efficiency'" (Žižek, The Plague, 2008, p. 27).

It is due to this "efficiency" that the Clod succeeds in persuading Thel to believe in what she believes, while the others fail. Her message seems to be the following: "True, we do not know everything about the real state of affairs, there are many questions which still remain unanswered; however, we are sure that what we believe in is true. Our ignorance is because we are not in a position to see the whole picture, although there are certainly people who do. Then, let us cast our doubts away and believe in our Cause."

This Pascalian gesture is an instance of what Louis Althusser (1918-1990) called the process of interpellation, by means of which “ideology 'acts' or 'functions' in such a way that it 'recruits' subjects among the individuals...or 'transforms' the individual into subjects” (Althusser, 1971, p.174). In an act of interpellation, ideology imposes its fantasy scenario on the subject by means of providing the network of meaning with a Master-Signifier which will redefine their worldviews. (Žižek, The Sublime, 2008, p.113; Žižek, Parallax, 2006, pp.37-49) That is to say, ideology provides a narrative which totalizes the free-floating signifiers by introducing a Master-Signifier. After that, it is the function of fantasy to give credit and credulity to this narrative by creating a consistent and unified image of the ideological edifice.

With the exception of the Cloud, both the Lilly and the Clod are directly interpellated by a supernatural visitant. In a sense, through the process of interpellation, they are inscribed in the texture of ideology; accept their respective roles inside their world; obey the voice of God and His command; and embrace their mission of spreading love and charity to all the creation:

'Rejoice, thou humble grass, thou new-born lily flower, Thou gentle maid of silent valleys and of modest brooks;

For thou shalt be clothed in light and fed with morning manna,

Till summer's heat melts thee beside the fountains and the springs

To flourish in eternal vales.' (Blake, 2007, p. 101)

But he that loves the lowly pours his oil upon my head, And kisses me, and binds his nuptial hands around my breast, And say; "Thou mother of my children, I have loved thee, And I have given thee a crown that none can take away." (Blake, 2007, p. 104)

It is only when Thel is successfully interpellated that she is allowed to enter the underworld. The question is: what exactly is this underworld? Is it really "another" world, separate from the world of innocence? In other words, are "innocence" and "experience" two different, contradictory, concepts? In order to provide the proper answer to this question, it is necessary to draw on Hegel's dialectical philosophy. 
In a proper dialectical process, two seemingly opposed concepts turn out to be two moments of the same concept. (Žižek, For They Know, 2008, p.70) That is to say, what we first take to be the simple negation of the thesis (the point of departure), when we reach the final moment of the dialectical movement (the so-called 'negation of negation'), appears to be nothing but the same point of departure which has lost all its determinations and is brought to the point of absolute negativity. For instance, in the dialectic of Being/Nothingness at the beginning of Logic, Hegel claims that if we perform an absolute abstraction from Being, that is, if we negate all its determinations, what remains is pure Nothingness. However, in spite of their identity, they are still not totally identical, since otherwise there could be no movement from one to the other in the first place. Therefore, Nothingness, which was the negation of Being, itself is negated and passes once again into Being, although this time this Being is not the absolute negativity which it was in the beginning of the dialectical process. It has got a minimum determination which is its non-Nothingness, and thereby we enter the domain the Determinate Being as opposed to the Pure Being of the first moment. (Hegel, 2010, §86-98) And the same structure is at work in the dialectics of Law/Crime. Apropos of explaining the dialectic of Law and crime, Žižek claims:

In the course of the dialectical process, the moment which, at first sight, appeared as the external limit of the point of departure proves to be nothing but the extreme of its negative self-relationship. . . universal law itself is nothing but universalized crime, crime brought to its extreme, to the point of self-negation, whereby the difference crime/law falls within crime. Law "dominates" crime when some "absolute crime" particularizes all other crimes, converts them into "mere particular crimes". (Žižek, For They Know, 2008, pp. 32-33)

In other words, what we take to be Law is nothing but Crime brought to its extreme, abstracted from all its determinations, and it is only through the 'negation of the negation', once the absolute Crime is posited as the point of exception, that we pass into the domain of particular crimes. (ibid, p.30) In other words, the difference between law and crime is not the difference between two externally related concepts, but the difference between the concept and its absolute negation, that is, between crime and absolute self-negativity. This point of absolute self-negativity is what is called the Law.

Following the same line of argument regarding Innocence/Experience, we can say that what at first glance seems to us to be an external opposition between two independent terms is, in fact, the same relationship between a concept and its absolute negation. Innocence is the name for the absolute abstraction from Experience, that is, it is the name for the Experience which is purged of all its determinations. It is only through the exclusion of Innocence qua Experiencebrought-to-the-point-of-self-negation that Experience becomes a universal concept and the set of particular experiences is complete. Therefore, the idea that Innocence precedes Experience is radically inverted, as also are all the readings of the poem which see Thel living in a pre-existent, pre-experience, and embryonic world. What is taken as the world of experience, separate from the "vales of Har", is the dark "underside", or better say, the rising bed of the world of innocence itself. In other words, through her passage to the underworld, Thel encounters the Real of the symbolic reality, that which has to remain hidden if the innocent life up there in the "vales of Har" is to run its smooth course. Without this terrifying abyss, "where the fibrous roots / of every heart on earth infixes deep its restless twists" (Blake, 2007, p. 105), innocence would not come into being in the first place. 
It is the knowledge of this repressed underside of the innocent life, of the "obscene injunction" (Žižek, For They Know, 2008, p.9) which she hears from the hollow pit ("Why a tender curb upon the youthful burning boy? / Why a little curtain of flesh on the bed of our desire?" (Blake, 2007, p. 106)), of the terror and destruction on which the utopian Har is built, that lead to Thel's final retreat from the underground. It is as if Thel realizes the fact that her life of purity is in reality the horrible life of the underworld in disguise. In other words, she comes to the awareness that the harmonious and organic life upstairs is nothing but a fantasy construction in order to blind the subjects to the appalling reality. Through crossing the borderline, the "eternal gates" (ibid, p.105) of the underworld, Thel enters the realm of the Real, and encounters the void of the Thing in its uncanny emptiness and flow of Jouissance.

In another sense, it could be said that in this encounter, Thel faces the paradoxical locus which is simultaneously her origin and her telos. If, as Marjorie Levinson points out, the fact that "'the name Thel is derived from a Greek root meaning desire' is no news to any serious reader of Blake" (Levinson, 1980, p. 287), then in her visit to the "hollow pit", Thel qua desire confronts her own cause. That is to say, desire is caused by the urge to fill in "the empty place of the Thing," as an attempt to suture the hole at the heart of the symbolic reality. (Žižek, The Sublime, 20o8, p. 150) However, in order to be effective, desire should remain ignorant of its own essence, of the fact that there is no such thing as the 'ultimate' object of desire. If desire stops its incessant movement, it will simply cease to exist. Therefore, in order to continue its existence, desire should keep the illusion that what it seeks to retrieve is a lost object to which it owns its origin. Any encounter with the empty place of this supposed origin will have irrevocable consequences. (Žižek, The Plague, 2008, p.61).

\section{Conclusion}

The Book of Thel reflects William Blake's opinion about the Romantic ideology. Blake's accurate critique of this ideology becomes more clear when we pay attention to the fact that the poem was written on the eve of the French Revolution, with its prospect of building a utopian society not unlike the world of the poem. In a sense, it seems that Blake saw the ultimate illusion of the Romantic ideology, of its organicism, of its fantasy of building an ideal world of innocence purged from any taints of evil, and of a unified society where every part supports the other elements and is in turn supported by them. After all, did not the destiny of the French Revolution, which was the actualization of the Romantic ideology on the social and political plane, prove the truth of Blake's prophecies? Was not the ruthless butchering of thousands of people in the name of freedom, fraternity and equality the Real of the ideological fantasies?

Therefore, the final scene of the poem, when terrified Thel runs back into the vales with a shriek, signifies her return into the phantasmatic world of the symbolic reality. In terms of the psychoanalytic theory, Thel does not succeed in traversing her fantasy and fails to identify with the ontological loss which underlies her social life. According to Bruce Fink (1995), "The traversing of fantasy is the process by which the subject subjectifies trauma, takes the traumatic event upon him or herself, and assumes responsibility for that jouissance" (p. 63). Instead of accepting this inherent conflict, she prefers to return to the peaceful world of fantasy. However, Thel's tragedy consists in the fact that, regardless of her choice, her place is already there in the dark world of the underground, a hollow pit which is her Real abode and to which she belongs. In other words, the Romantic ideology, as Blake tries to show, consists of a double illusion, the first 
one being that of the two worlds of innocence and experience, different and separate from each other, and the second one being that of the possibility of leading a pure life of innocence not contaminated by taints of experience.

Later in his career, Blake tried to account for the apparent deficiencies of the Romantic ideology championed by Rousseau and his followers. Of course, what he tried to do was to change the fantasy scenario, to rewrite the ideological narrative, in his own way. In other words, he planned to create a system of his own instead of being a slave to another man's. As he put it in the mouth of Los (the protagonist of Blake's later epics), "I must Create a System, or be enslav'd by another man's / I will not Reason \& Compare: my business is to Create" (Blake, 2007, p. 676). It seems that the traumatic effect of the encounter with the Real was too much for Blake to endure. However, what Blake did not probably pay attention to was the fact that in creating a system, he would not achieve the freedom he aspired for, since at the end of the day he would be the one serving the purposes of his new ideology.

\section{References}

Althusser, L. (1971). Lenin and Philosophy and Other Essays. (B. Brewster, Trans.) New York: Monthly Review Press.

Blake, W. (2007). Blake: The Complete Poems (3 ed.). (W. H. Stevenson, Ed.) Harlow: Pearson Longman. Bloom, H. (2008). William Blake. New York: Bloom's Literary Criticism.

Fink, B. (1995). The Lacanian Subject: Between Language and Jouissance. Princeton: Princeton University Press.

Frye, N. (1947). Fearful Symmetry: A Study of William Blake. Princeton: Princeton University Press.

Gallant, C. (1978). Blake and the Assimilation of Chaos. Princeton: Princeton University Press.

Hegel, G. W. (2010). The Science of Logic. (G. D. Giovanni, Ed., \& G. D. Giovanni, Trans.) Cambridge: Cambridge University Press.

John, B. (1974). Supreme Fictions. Toronto: McGill-Queen's University Press.

Levinson, M. (1980). "The Book of Thel" by William Blake: A Critical Reading. ELH, 47(2), 287-303.

Lovejoy, A. O. (1964). The Great Chain of Being: A Study of the History of an Idea. London: Harvard Univeristy Press.

McFarland, Thomas (1981). Romanticism and the Forms of Ruin. Princeton: Princeton University Press.

Murray, C. J. (2004). Encyclopedia of the Romantic Era: 1760-1850. New York: Fitzroy Dearborn.

Murray, E. B. (1981). Thel, "Theyphthora," and the Daughters of Albion. Studies in Romanticism, 2o(3), 275297.

Pascal, B. (1999). Pensées and Other Writings. (A. Levi, Ed., \& H. Levi, Trans.) New York: Oxford University Press.

Popkin, Jeremy D. A History of Modern France. (4 ${ }^{\text {th }}$ ed.). London: Routledge.

Quinney, L. (2009). William Blake on Self and Soul. London: Harvard University Press.

Roberts, J. (2007). William Blake's Poetry. London: Continuum.

Simpkins, S. (1988). "The Book of Thel" and the Romantic Lament. South Central Review, 5(1), 25-39.

Williams, J. B. (2005). William Blake: A Literary Life. New York: Palgrave.

Žižek, S. (1993). Tarrying with the Negative: Kant, Hegel, and the Critique of Ideology. Durham: Duke University Press.

Žižek, S. (1999). The Ticklish Subject: The Absent Centre of Political Ontology. London : Verso.

Žižek, S. (2006). The Parallax View. London: MIT Press.

Žižek, S. (2008). For They Know Not What They Do (2nd ed.). London: Verso.

Žižek, S. (2008). The Plague of Fantasies (2 ed.). London: Verso.

Žižek, S. (2008). The Sublime Object of Ideology (2nd ed.). London: Verso. 
73 | Beyond the Veil of Fantasy: "The Book of Thel" and the Critique of Romantic Ideology

Ghiasuddin Alizadeh received his BA degree in English Language and Literature from Shahid Beheshti University in 2009. He later received his MA degree in English Literature from Shahid Beheshti University in 2013. Currently, he is a $\mathrm{PhD}$ candidate of English Literature in Shahid Beheshti University, working on his PhD dissertation entitled "The Dawn of Freedom or the Dusk of Captivity: A Psychoanalytic Study of the Poetry of the Major British Romantic Poets". His main research interests include Romantic Literature, Psychoanalytic Theory, Žižek Studies, Marxist and Post-Marxist Criticism.

Dr. Shideh Ahmadzadeh received her BA degree from Ferdowsi University, Mashad in 1989. She later pursued her studies through the MA course in English Literature at Tehran University and was recognized as the first-best student in BA and MA degrees. She started her PhD degree under the supervision of Professor Gordon Campbell at the University of Leicester in 1995. Her Thesis is entitled "Narratives of Eros and Desire in Shakespeare's Poetry". She defended her thesis in February 1999 and moved back to Iran. She is now a full-time lecturer at Shahid Beheshti University and has been teaching English Literature at BA, MA, and PhD levels. Her main research interests include Psychoanalytic Theory, Renaissance Literature, Shakespeare studies, Drama, and Metaphysical Poetry. 